\title{
Service Performance Indicator Sebagai Upaya Peningkatan Kualitas Pelayanan Publik di Stasiun Lempuyangan Yogyakarta
}

\author{
Deby Febriyan Eprilianto \\ E-mail: deby_febriyan_eprilianto@yahoo.co.id
}

This study aims to identify and explain the improvement of the quality of public services through the optimization of transportation policies in Lempuyangan Railway Station Yogyakarta. This study is a descriptive qualitative research and taking place in PT KAI Yogyakarta Region VI Operations and in station Lempuyangan. The results of this study concluded that: (1) improving the quality of public services through the optimization of transport policies in station Lempuyangan Yogyakartathat is based on the Minister of Transportation Regulation Number 09 year 2011 on Minimum Service Standards (MSS) for public transportation by train has been implemented optimally by implementing Service Performance Indicator (SPI) program, which consists of eleven indicators namely : (a) SPI Information, (b) SPI Cleanliness and Health, (c) SPI Ticket Service, (d) SPI Security, (e) SPI staff and Officers, (f) SPI Waiting Room, (g) SPI Public Facilities, (H) SPI Peron, (i) SPI parking, (j) SPI Lighting, and (k) SPI Toilet, and (2) the application of SPM and SPI optimally made Lempuyangan station got third winner in the best station award in 2013.

Keywords: Quality Improvement Services, Transportation Policy.

\section{PENDAHULUAN}

Seiring dengan perkembangan teknologi alat transportasi, masyarakat memiliki peluang lebih besar untuk memilih jasa transportasi yang sesuai dengan kebutuhannya. Kereta api adalah salah satu moda transportasi yang banyak menjadi pilihan masyarakat, khususnya para pengguna jasa transportasi yang membawa atau mengangkut barang dalam jumlah banyak ke antar daerah atau provinsi karena jasa transportasi kereta api memiliki kemampuan untuk mengangkut penumpang dan barang dalam jumlah besar, nyaman, mempunyai tingkat pencemaran yang rendah, serta lebih efisien dibandingkan dengan moda transportasi darat lainnya. Keunggulan berbeda yang dimiliki moda transportasi kereta api menjadikan sebagai pilihan pengguna jasa transportasi khususnya di Pulau Jawa.

Kini peranan transportasi tidak hanya melayani aktivitas pergerakan manusia dan barang namun juga merangsang timbulnya beberapa aktivitas baru yang sebelumnya tidak ada. Pelayanan jasa transportasi berperan penting sebagai pendorong dan sekaligus penunjang dari aktivitas perekonomian, oleh karena itu transportasi dianggap sebagai urat 
nadi perekonomian nasional. Apabila transportasi tersendak atau berhenti, maka dampaknya adalah terjadinya stagnasi aktivitas ekonomi masyarakat. Pentingnya peranan transportasi membuat persaingan usaha di bidang ini semakin ketat dan menantang.

PT KAI sebagai satu-satunya penyedia jasa transportasi kereta api di Indonesia perlu memperhatikan kepuasan pelanggan. Untuk mencapai kepuasan pelanggan yang maksimum maka perusahaan harus memperhatikan kualitas produk dan jasa yang dihasilkan, dan menyadari pentingnya kualitas pelayanan kepada pelanggan meskipun hal ini tidak mudah diimplementasikan oleh perusahaan. Perusahaan lebih mudah memberikan kepuasan kepada pelanggannya jika mampu memahami perilaku pelanggan.

Kepuasan penumpang kereta api salah satunya ditentukan oleh kualitas pelayanan yang diberikan, seperti keunggulan dari sistem pelayanan tiket (reservasi), baik dari segi kemudahan untuk mendapatkannya, kenyamanan dan keamanan dalam pelayanannya, termasuk keramahan dari petugas loket, ketersediaan informasi yang jelas dan mudah diakses, suasana kenyamanan dan keamanan di loket-loket penjualan tiket.

Kepuasan pelanggan telah menjadi konsep sentral dalam wacana bisnis dan manajemen. Kepuasan pelanggan terhadap suatu produk atau jasa juga akan berdampak pada perilaku pelanggan selanjutnya. Loyalitas merek menggambarkan kondisi bahwa pelanggan mempunyai sikap positif terhadap sebuah merek, mempunyai komitmen pada merek tersebut dan bermaksud meneruskan pembeliamya di masa mendatang, artinya jika pelanggan puas terhadap pilihannya maka dia akan loyal terhadap pilihannya tersebut. Diharapkan pelanggan yang puas akan membeli lebih banyak sepanjang waktu dan membeli lebih sering. Pelanggan yang puas diharapkan akan merekomendasikan kepada kerabat dan teman-temannya sehingga terjalin hubungan antara penjual, pelayanan, kepuasan, dan keuntungan secara langsung. Begitu juga dengan penumpang kereta api, apabila penumpang merasa puas dengan pelayanan yang diberikan maka mereka akan merekomendasikan kepada semua orang yang dikenalnya untuk menggunakan jasa transportasi kereta api. Selain itu penumpang akan selalu menggunakan kereta api untuk melakukan perjalanannya karena pelayanan yang dirasakan baik untuk mereka pertahankan. Hal ini akan menyebabkan hubungan yang baik antara penumpang dan petugas atau pegawai yang bekerja di stasiun maupun di dalam kereta api.

Selain kepuasan pelanggan, hal terpenting lainnya yaitu penyediaan fasilitas umum yang dibutuhkan oleh penumpang. Kebanyakan perusahaan menyediakan fasilitas 
umum untuk memberikan kepuasan kepada penumpang. Fasilitas umum disediakan terkadang jauh dari harapan penumpang sehingga terkesan kurang optimalnya dalam penyediaan fasilitas umum dalam rangka memberikan kepuasan penumpang. Dengan kata lain, pelanggan yang sudah puas pada suatu produk belum tentu akan selalu loyal pada produk tersebut.

Yogyakarta merupakan salah satu tujuan perjalanan yang banyak dilalui perjalanan kereta api, disamping kota ini sebagai kota pendidikan dan juga kota wisata, sehingga banyak orang yang datang dan berangkat di stasiun-stasiun kereta api Yogyakarta khususnya Stasiun Lempuyangan. Transportasi kereta api harus mampu bersaing dengan moda trasnportasi lainnya. Salah satu pilihan moda transportasi lainnya seperti angkutan udara dengan sistem low cost carrier (pesawat harga tiket murah) menjadi tantangan bagi PT KAI untuk memberikan pelayanan yang lebih baik, termasuk pelayanan tiket.

Stasiun kereta api kelas ekonomi selama ini hampir identik dengan jorok, kumuh, dan tidak teratur. Begitu juga dengan stasiun Lempuyangan yang saat ini sedang berbenah untuk menghapus stigma ini. Karena merupakan satu-satunya stasiun kereta api ekonomi di Yogyakarta, menjadikan stasiun Lempuyangan sebagai pusat aktivitas masyarakat khususnya aktivitas transportasi. Hal ini mengakibatkan sering terlihat keadaan stasiun yang amburadul atau tidak terawat. Seperti penyediaan tempat parkir yang kurang sehingga penumpang yang membawa kendaran bermotor harus parkir ditepi jalan utama yang mengakibatkan kemacetan, terlihat antrean yang panjang sehingga terkesan berjubel dan tidak teratur, ruang tunggu yang tidak memadai dan tidak mencukupi yang mengakibatkan banyak penumpang yang harus duduk lesehan dilantai stasiun, sering terjadi kehilangan barang, kecopetan dan keluhan penumpang yang memperlihatkan sistem keamanan stasiun yang kurang baik. Hal ini menjadi tugas dan tanggung jawab PT KAI Daerah Operasi VI Yogyakarta untuk melakukan perbaikan di stasiun Lempuyangan.

Permasalahan pelayanan di stasiun Lempuyangan dapat terlihat juga dari pengadaan fasilitas umum yang kurang memadai, baik secara jumlah maupun keadaannya. Banyaknya fasilitas umum seperti tempat duduk, tempat sampah, toilet, tempat parkir, mushola dan lain sebagainya masih dalam keadaan yang kurang terawat bahkan jumlahnya tidak sesuai dengan jumlah yang seharusnya ada sehingga tidak semua penumpang dapat menggunakan dan memanfaatkan fasilitas umum yang ada. Perbaikan 
di stasiun Lempuyangan sebenarnya sudah dilakukan untuk menciptakan pelayanan yang baik kepada penumpang kereta api. Selain itu perubahan kereta api ekonomi menjadi ekonomi AC harus disertai dengan perbaikan pelayanan disetiap stasiun kereta api enomomi seperti halnya stasiun Lempuyangan.

PT KAI Daerah Operasi VI Yogyakarta melakukan survei tentang kepuasan di stasiun Lempuyangan pada tahun 2012 sebagai berikut.

Tabel 1. Gambaran Tingkat Kepuasan di Stasiun Lempuyangan Yogyakarta 2012

\begin{tabular}{clcc}
\hline \multirow{2}{*}{ Kode } & \multicolumn{1}{c}{ Faktor } & \multicolumn{2}{c}{ Rata-rata } \\
\cline { 3 - 4 } & & $\begin{array}{c}\text { Tingkat } \\
\text { Kepuasan }\end{array}$ & $\begin{array}{c}\text { Prioritas } \\
\text { Penanganan }\end{array}$ \\
\hline \hline 1 & Harga tiket yang ditawarkan & 3.04 & 3.37 \\
2 & Kebersihan di stasiun/shelter & 2.92 & 3.56 \\
3 & Kebersihan didalam kereta & 2.91 & 3.59 \\
4 & Kebersihan toilet di stasiun/shelter & 2.76 & 3.62 \\
5 & Keamanan pada saat berada di stasiun/kereta & 2.96 & $\mathbf{3 . 8 0}$ \\
6 & Kenyamanan dari gangguan cuaca & $\mathbf{2 . 6 8}$ & 3.29 \\
7 & Kenyamanan pada saat berada didalam kereta & 3.23 & 3.40 \\
8 & Kenyamanan pada saat naik/turun dari kereta & 2.99 & 3.30 \\
9 & Luas stasiun/shelter & 3.02 & $\mathbf{3 . 0 4}$ \\
10 & Jumlah tempat duduk di stasiun & 2.79 & 3.35 \\
11 & Jumlah tempat duduk didalam kereta & 3.21 & 3.53 \\
12 & Informasi berkaitan dengan jadual & 3.19 & 3.74 \\
13 & Ketepatan antara jadual dengan kenyataan & $\mathbf{3 . 2 4}$ & 3.79 \\
14 & Keramahan petugas dalam melayani penumpang & 2.94 & 3.48 \\
15 & Pemahaman petugas akan jadual & 3.08 & 3.39 \\
16 & Penerangan didalam kereta & 3.15 & 3.35 \\
17 & Sirkulasi udara didalam kereta & 3.06 & 3.43 \\
& Rata-rata Keseluruhan & $\mathbf{3 . 0 1}$ & $\mathbf{3 . 4 7}$ \\
\hline
\end{tabular}

Keterangan :

Skala pengukuran $\quad: 1-4$

$0,00-1,00 \quad$ : sangat buruk

$1,00-2,00 \quad$ : buruk

$2,00-3,00 \quad$ : baik

3,00-4,00 : sangat baik

Sumber : PT KAI Daerah Operasi VI Yogyakarta Tahun 2012

Berdasarkan data di atas, dapat dikatakan tingkat kepuasan pelanggan lebih rendah dibandingkan prioritas penanganan yang dilakukan oleh PT KAI Daerah Operasi VI Yogyakarta di Stasiun Lempuyangan Yogyakarta dalam skala pengkuruan 1-4. Tingkat kepuasan pelanggan tersebut sudah tergolong dalam kategori baik. Tetapi tingkat penanganan yang dilakukan, tidak menutup kemungkinan mempengaruhi jumlah keluhan pelanggan kereta api di stasiun Lempuyangan yang mengalami kenaikan dan penurunan yang tidak menentu disetiap tahunnya. Sebagai perbandingan, kepuasan pelanggan dapat dipengaruhi oleh banyaknya keluhan dari pelanggan seperti yang terdapat pada tabel jumlah keluhan pelanggan di stasiun Lempuyangan Yogyakarta seperti berikut ini. 
Tabel 2. Jumlah Keluhan Pelanggan

\begin{tabular}{|c|c|}
\hline Tahun & $\begin{array}{c}\text { Stasiun } \\
\text { Lempuyangan }\end{array}$ \\
\hline 2008 & 243 \\
\hline 2009 & 368 \\
\hline 2010 & 169 \\
\hline 2011 & 295 \\
\hline 2012 & 311 \\
\hline
\end{tabular}

Sumber : Ditjen Perkeretaapian, Pusdatin Dephub, \& PT KAI 2012

Dari Tabel 2, dapat diketahui bahwa keluhan pelanggan di stasiun kereta api Lempuyangan Yogyakarta tahun 2008 sampai 2009 semakin meningkat sebesar 125 pelanggan. Sementara itu, meskipun di Stasiun Lempuyangan Yogyakarta terdapat perbaikan dalam pelayanan pelanggan sehingga pada rentang tahun 2009 sampai 2010 mengalami penurunan secara signifikan, namun jumlah keluhan pelanggan meningkat kembali secara signifikan pada tahun 2010 sampai 2011 dan 2011 sampai 2012. Jumlah keluhan di stasiun Lempuyangan salah satunya disebabkan karena hanya melayani kereta api kelas ekonomi saja. Sehingga kereta api yang berhenti ataupun yang beroperasi di stasiun Lempuyangan merupakan kereta api kelas ekonomi dan ekonomi AC.

Permasalahan-permasalahan tersebut tidak luput dari perhatian Pemerintah dengan mengeluarkan berbagai kebijakan untuk mengatasinya. Berbagai kebijakan publik dibidang transportasi ditetapkan untuk mengatasi permasalahan transportasi yang ada. Salah satunya peraturan Menteri Perhubungan Nomor 09 tahun 2011 tentang Standar Pelayanan Minimum (SPM) untuk angkutan orang dengan kereta api. Peraturan ini mengatur tentang pelayanan yang seharusnya didapatkan oleh masyarakat sebagai penumpang kereta api, baik di stasiun maupun didalam kereta api. Penerapan SPM sejauh ini masih belum dilaksanakan secara maksimal di stasiun-stasiun yang ada, hal ini dikarenakan tidak diaturnya sanksi bagi yang melanggarnya sehingga stasiun melaksanakan SPM berdasarkan keadaan dan kemampuan masing-masing begitu juga di stasiun Lempuyangan. Ketidakmaksimalan penerapan peraturan ini terlihat dari berbagai permasalahan yang ada disetiap stasiun. 
Pelayanan publik merupakan hal terpenting dalam penyelenggaraan negara. Menurut Agus Dwiyanto pelayanan publik mencakup pelayanan untuk memenuhi kebutuhan barang publik, kebutuhan dan hak dasar, kewajiban pemerintah dan Negara, dan komitmen nasional (2011:22). Warga negara berharap pemerintah dapat melayani dengan kejujuran dan pengelolaan sumber penghasilan secara tepat, dan dapat dipertanggungjawabkan kepada publik. Pelayanan publik yang adil dan dapat dipertanggungjawabkan menghasilkan kepercayaan publik. Dibutuhkan etika pelayanan publik sebagai pilar dan kepercayaan publik sebagai dasar untuk mewujudkan pemerintah yang baik. Sedangkan ciri-ciri pelayanan publik menurut Agus Dwiyanto (2011:23) dapat dilihat dari tabel berikut.

Tabel 3. Ciri-ciri Pelayanan Publik

\begin{tabular}{|l|l|l|}
\hline No & \multicolumn{1}{|c|}{ Ciri-ciri } & \multicolumn{1}{|c|}{ Pelayanan Publik } \\
\hline & Sifat barang dan jasa & $\begin{array}{l}\text { Barang publik, barang semi publik, dan } \\
\text { memiliki eksternalitas }\end{array}$ \\
\hline $\begin{array}{l}\text { Resiko kegagalan } \\
\text { penyelenggaraan }\end{array}$ & $\begin{array}{l}\text { Resiko kolektif, banyak orang, dan } \\
\text { bersama }\end{array}$ \\
\hline & $\begin{array}{l}\text { Akses warga terhadap pelayanan } \\
\text { Keterkaitan dengan pencapaian }\end{array}$ & Tanggung jawab Negara \\
\hline Dasar penyelenggaraanya & $\begin{array}{l}\text { Konstitusi, kebijakan publik, dan } \\
\text { peraturan perundangan }\end{array}$ \\
\hline & Lembaga penyelenggara & $\begin{array}{l}\text { Intsansi pemerintah, korporasi, dan } \\
\text { lembaga nirlaba }\end{array}$ \\
\hline & Sumber pembiayaan & Anggaran, subsidi pemerintah, user fee \\
\hline
\end{tabular}

Pelayanan publik tidak harus diselenggarakan oleh lembaga pemerintah melainkan lembaga non-pemerintah lainnya yang menggunakan sumberdayanya untuk menyelenggarakan pelayanan yang termasuk dalam barang publik, kebutuhan dasar, kebutuhan strategis, dan komitmen nasional maka pelayanan yang mereka selenggarakan dapat disebut sebagai pelayanan publik. Lembaga non-pemerintah dapat menjadi lembaga penyelenggara layanan publik apabila mereka berpastisipasi dalam penyelenggaraan layanan publik.

Pelayanan publik sudah seharusnya memperhatikan kualitas pelayanan karena pelayanan yang baik adalah awal bagi tumbuhnya kepercayaan masyarakat kepada pemerintah, yang selanjutnya akan menjadi penentu pemberdayaan masyarakat. Dalam konteks ini, pengukuran mengenai kualitas pelayanan merupakan perbandingan antara 
pelayanan yang diharapkan (expected service) dengan pelayanan yang diterima (perceived service). Dalam metode pengukuran ini, penilaian masyarakat selaku pelanggan berperan penting dalam mengukur kualitas pelayanan publik. Pengukuran kualitas pelayanan publik didasarkan pada indikator-indikator yaitu : 1) tangibles, artinya kualitas pelayanan yang berupa sarana fisik perkantoran, ruang tunggu, dan lain-lain. 2) reliability, yakni kemampuan dan keandalan untuk menyediakan pelayanan yang terpercaya, 3) responsiveness, yakni kesanggupan untuk membantu dan menyediakan pelayanan secara cepat dan tepat, serta tanggap terhadap keinginan pelanggan, 4) assurance, yakni kemampuan dan keramahan serta sopan santun pegawai dalam meyakinkan dan menumbuhkan kepercayaan pelanggan, dan 5) emphaty, yakni sikap tegas tetapi penuh perhatian dari pegawai terhadap pelanggan (Zeitham, Parasuraman, dan Berry dalam Ratminto dan Atik S.Winarsih, 2010:175).

Lingkup dari studi kebijakan publik sangat luas karena mencakup berbagai bidang dan sektor seperti ekonomi, politik, sosial, budaya, hukum, dan sebagainya. Disamping itu dilihat dari hirarkirnya kebijakan publik dapat bersifat nasional, regional maupun lokal seperti undang-undang, peraturan pemerintah, peraturan presiden, peraturan menteri, peraturan pemerintah daerah/provinsi, keputusan gubernur, peraturan daerah kabupaten/kota, dan keputusan bupati/walikota. Thomas R Dye (Dalam Budi Winarno, 2010:20) mendefinisikan kebijakan publik sebagai "is whatever government choose to do or not to do (apapun yang dipilih pemerintah untuk dilakukan atau untuk tidak dilakukan)". Definisi ini menekankan bahwa kebijakan publik adalah mengenai perwujudan "tindakan" dan bukan merupakan pernyataan keinginan pemerintah atau pejabat publik semata. Di samping itu pilihan pemerintah untuk tidak melakukan sesuatu juga merupakan kebijakan publik karena mempunyai pengaruh (dampak) yang sama dengan pilihan pemerintah untuk melakukan sesuatu.

Departemen Perhubungan (2005: 27) menjelaskan bahwa "transportasi adalah kegiatan pemindahan barang (muatan) dan penumpang dari suatu tempat ke tempat lain. Transportasi dibagi menjadi : 1) tranportasi darat, 2) transportasi air, dan 3) transportasi udara". Ketiga jenis transportasi inilah yang kemudian memunculkan berbagai bentuk moda transportasi yang digunakan oleh masyarakat untuk membantu dalam aktivitasnya sehari-hari. Seperti misalnya transportasi darat yang memunculkan moda transportasi sepeda, sepeda motor, mobil, bus, kereta api dan lain sebagainya. 
Dari pengertian di atas, maka kebijakan transportasi adalah "keputusan yang dibuat oleh pemerintah sebagai upaya untuk memecahkan permasalahan di bidang transportasi demi memenuhi kepentingan publik". Permasalahan di bidang transportasi di artikan sebagai segala masalah-masalah yang berkaitan dengan pemindahan barang dan orang dari satu tempat ke tempat lain. Pemerintah memiliki kewajiban untuk mengatur bidang transportasi agar terciptanya sistem transportasi yang memadai.

Suatu kebijakan yang telah diambil sebagai alternatif pemecahan masalah harus diimplementasikan, yakni dilaksanakan oleh badan-badan administrasi maupun agenagen pemerintah di tingkat bawah. Riant Nugroho mengemukakan bahwa implementasi kebijakan pada prinsipnya adalah cara agar sebuah kebijakan dapat mencapai tujuannya. Tidak lebih dan tidak kurang. Untuk mengimplementasikan kebijakan publik, maka ada dua pilihan langkah yang ada, yaitu langsung mengimplementasikan dalam bentuk program-program atau melalui formulasi kebijakan derivate atau turunan dari kebijakan publik tersebut (2008: 432).

Proses implementasi merupakan sebuah abstraksi atau performansi suatu pelaksanaan kebijakan yang pada dasarnya secara sengaja dilakukan untuk meraih kinerja implementasi kebijakan yang tinggi yang berlangsung dalam hubungan berbagai variabel. Keberhasilan implementasi kebijakan akan ditentukan oleh banyak faktor, dan masingmasing faktor tersebut akan saling berhubungan satu sama lain.

Teori lain yang dikemukakan oleh para ahli yaitu teori Donald Van Meter dan Carl Van Horn pada tahun 1975. Teori ini dijelaskan oleh Riant Nugroho sebagai berikut.Model ini mengandaikan bahwa implementasi kebijakan berjalan secara linear dari kebijakan publik, implementor, dan kinerja kebijakan publik. Beberapa variabel yang dimasukkan sebagai variabel yang mempengaruhi kebijakan publik adalah variabel berikut : 1) aktivitas implementasi dan komunikasi antar organisasi, 2) karakteristik agen pelaksana / implementor, 3) kondisi ekonomi, sosial, dan politik, dan 4) kecenderungan (disposition) pelaksana / implementor (2008:438).

\section{METODE PENELITIAN}

Penelitian ini adalah penelitian kualitatif deskriptif untuk menjelaskan dan menggambarkan secara mendalam tentang peningkatan kualitas pelayanan publik melalui optimalsasi penerapan kebijakan transportasi di stasiun Lempuyangan Yogyakarta. Subjek penelitian ini yaitu Kepala PT KAI Daerah Operasi VI Yogyakarta, Manajer dan 
satu orang staf SDM dan umum, Manajer dan staf orang staf Pelayanan, Manajer Operasi, Manajer Sarana, Kepala UPT Stasiun Kelas Besar Lempuyangan, Kepala bagian Pelayanan Stasiun, Kepala Bagian Kemanan, Kebersihan, Kesehatan, dan Ketertiban Stasiun, dua orang petugas ticketing dan dua orang penumpang kereta api di stasiun Lempuyangan Yogyakarta. Instrumen penelitian adalah peneliti sendiri. Sumber dan jenis data yaitu data primer dan data sekunder. Teknik pengumpungan data yaitu wawancara, observasi dan dokumentasi. Teknik analasis data menggunakan teknik analisis interaktif. Pengujian keabsahan data menggunakan teknik triangulasi sumber dan metode.

\section{HASIL PENELITIAN DAN PEMBAHASAN}

Pelayanan publik merupakan hal terpenting dalam penyelenggaraan negara. Menurut Agus Dwiyanto (2011: 22) pelayanan publik mencakup pelayanan untuk memenuhi kebutuhan barang publik, kebutuhan dan hak dasar, kewajiban pemerintah dan Negara, dan komitmen Nasional. Kebutuhan publik sangatlah beragam, salah satunya pemenuhan kebutuhan publik dalam bidang transportasi. Transportasi memiliki peranan yang penting dalam pemenuhan kebutuhan masyarakat. Transportasi di Indoensia oleh Departemen Perhubungan (2005;27) dibagi menjadi tiga yaitu : 1) transportasi darat, 2) transportasi air, dan 3) transportasi udara, dari ketiga pembagian transportasi ini memunculkan berbagai alat transportasi, misalkan transportasi darat memunculkan alat transportasi darat seperti kereta api, mobil, sepeda, bus, dan lain sebagainya.

Pelayanan publik tidak harus disediakan oleh lembaga pemerintah melainkan lembaga non-pemerintah lainnya dapat memberikan pelayanan publik melalui sumber daya yang dimilikinya, seperti pelayanan publik dalam bidang transportasi khususnya transportasi kereta api di Indonesia dikelola oleh PT Kereta Api Indonesia (KAI) Persero. Konsep pelayanan publik erat kaitannya dengan kepuasan pelanggan, begitu juga dengan pelayanan publik dalam bidang transportasi kereta api harus memperhatikan tingkat kepuasan penumpang. Seperti halnya kondisi pelayanan publik dalam bidang transportasi di Indonesia memiliki potret yang kurang memuaskan, hal ini terlihat masih rendahnya tingkat kepuasan penumpang terutama pada stasiun kelas ekonomi dan kereta api kelas ekonomi. Pada kelas ekonomi terlihat pelayanan yang diberikan kepada penumpang masih amburadul dan terkesan kumuh atau kotor. Kondisi seperti ini yang kemudian mengakibatkan berbagai permasalahan dalam pelayanan publik yang diberikan kepada 
penumpang disemua stasiun yang ada di Indonesia, termasuk di stasiun Lempuyangan Yogyakarta.

Permasalahan yang terjadi pada pelayanan publik dibidang transportasi kereta api tak luput dari perhatian pemerintah untuk mengatasinya, salah satunya dengan menetapkan kebijakan publik. Berbagai kebijakan publik khususnya kebijakan perkeretaapian ditetapkan untuk mengatasi permasalahan yang terjadi dalam pelayanan publik bidang transportasi kereta api. Salah satu kebijakan perkeretaapian yang telah ditetapkan oleh pemerintah melalui Kementerian Perhubungan yaitu Peraturan Menteri Perhubungan Nomor 09 Tahun 2011 tentang Standar Pelayanan Minimu (SPM) untuk angkutan orang dnegan kereta api. Peraturan ini diharapkan dapat mengatasi permasalahan yang terjadi pada pelayanan publik dalam bidang transportasi kereta api.

Pada peraturan ini diatur dua SPM yang harus dipenuhi oleh pelaksana kebijakan yaitu, SPM di stasiun kereta api dan SPM di dalam perjalanan. SPM di stasiun kereta api harus disediakan informasi yang jelas dan mudah dibaca, loket, ruang tunggu, tempat ibadah, toilet, dan tempat parkir, kemudahan naik dan turun penumpang, fasilitas penyandnag cacat, dan fasilitas keselamatan dan keamanan. Sedangkan dalam penerapan SPM diklasifikasikan dalam tigas jenis stasiun, yaitu stasiun besar, stasiun sedang dan stasiun kecil. Penerapan peraturan ini diharapakan dapat meningkatkan kualitas pelayanan publik dalam bidang pelayanan transportasi kereta api. PT KAI mempunyai kewajiban menerpakan SPM dalam peraturan tersebut di semua staisun yang ada dengan membagi kedalam daerah operasi sebagai berikut.

Tabel 4. Pembagian Daerah Operasi PT KAI Persero

\begin{tabular}{|c|l|l|}
\hline No & \multicolumn{1}{|c|}{ Daerah Operasi } & \multicolumn{1}{c|}{ Wilayah } \\
\hline & Daerah Operasi I & Jakarta \\
\hline & Daerah Operasi II & Bandung \\
\hline & Daerah Operasi III & Cirebon \\
\hline & Daerah Operasi IV & Semarang \\
\hline & Daerah Operasi V & Purwokerto \\
\hline & Daerah Operasi VI & Yogyakarta \\
\hline & Daerah Operasi VII & Madiun \\
\hline & Daerah Operasi VIII & Surabaya \\
\hline & Daerah Operasi IX & Jember \\
\hline
\end{tabular}

Sumber : diolah Deby Febriyan Eprilianto dari berbagai sumber, 2013

Masing-masing daerah operasi bertanggungjawab terhadap stasiun-stasiun yang ada, begitu juga dengan Daerah Operasi VI Yogyakarta yang memiliki 24 stasiun, salah 
satunya staisun Lempuyangan Yogyakarta. Staisun Lempuyangan merupakan satusatunya stasiun besar kelas ekonomi yang ada di Yogyakarta. Penerapan SPM dalam peraturan ini di staisun Lempuyangan sebagai upaya untuk mengatasi permasalahan yang ada dan untuk meningkatkan kualitas pelayanan publik. Untuk optimalisasi penerapan SPM dalam peraturan ini di stasiun Lempuyangan, PT KAI Daerah Operasi VI Yogyakarta menetapkan program pelaksanaan yaitu Service Performance Indicator (SPI) yang terdiri dari 11 indikator yaitu (a) SPI Informasi, (b) SPI Kebersihan dan Kesehatan, (c) SPI Pelayanan Tiket, (d) SPI Keamanan, (e) SPI Staf dan Petugas, (f) SPI Ruang Tunggu, (g) SPI Fasilitas Umum, (h) SPI Peron, (i) SPI Parkir, (j) SPI Pencahayaan, dan (k) SPI Toilet. Dalam penetapan SPI telah menyesuaikan SPM yang ada dalam peraturan, sehingga SPM yang telah diatur dimasukkan kedalam SPI sebagai berikut.

1. SPM penyediaan informasi yang jelas dan mudah dibaca dimasukkan ke dalam SPI informasi, penyediaan informasi di stasiun Lempuyangan masih menggunakan papan manual yang apabila terdapat pembaharuan informasi harus diganti dnegan kertas baru atau hanya sekedar dicoret menggunakan tinta, jumlah papan informasi yang disediakan nomor dan nama KA, jadwal kedatangan dan keberangkatan KA, tarif $\mathrm{KA}$, rute KA, jumlah kursi yang masih kosong, dan audio informasi.

2. SPM loket dimasukkan ke dalam SPI pelayanan tiket, tersedia 4 loket di stasiun Lempuyangan tetapi loket yang beroperasi hanya 3, sehingga sering terjadi antrian yang panjang hampir setiap hari.

3. SPM ruang tunggu dimauskkan ke dalam SPI ruang tunggu, ruang tunggu disediakan dengan penempatan ditiga lokasi yaitu ruang tunggu diloket reservasi tiket, ruang tunggu diperon, dan ruang tunggu khusus smoking area, penempatan ini disesuaikan dengan kebutuhan penumpang KA, tetapi jumlah kursi yang disediakan masih belum bisa menampung jumlah penumpang yang ada.

4. SPM tempat ibadah dimasukkan ke dalam SPI fasilitas umum, terdapat mushola yang luas untuk penumpang yang akan melakukan kegiatan ibadah, selain itu juga disediakan kios-kios untuk penumpang yang akan membeli makanan atau oleh-oleh.

5. SPM toilet dimasukkan ke dalam SPI toilet, toilet di stasiun Lempuyangan sudah dipisah antara toilet laki-laki dan perempuan dengan jumlah masing-masing 3, untuk kelas stasiun besar jumlah ini snagat kurang sehingga sering terjadi antrian dan juga tidak disediakannya toilet khusus untuk penyandang cacat. 
6. SPM tempat parkir dimasukkan ke dalam SPI parkir, penyediaan tempat parkir di staisun Lempuyangan masih belum bisa menampung jumlah kendaraan yang ada, apalagi untuk kendaran roda 4 atau mobil masih belum disediakan tempat parkir, sehingga masing meberdayakan tepi jalan Lempuyangan yang sering mengakibatkan kemacetan. Penyediaan tempat parkir menjadi persoalan yang belom bisa terselesaikan karena keterbatasan lahan.

7. SPM fasilitas kemudahan naik dan turun penumpang dimasukkan ke dalam SPI peron, penyediaan peron sudah diatur sedemikian rupa untuk kemudahan naik dan turun penumpang seperti pengaturan kemiringan ramp dan penyediaan bancik.

8. SPM fasilitas kesehatan dimasukkan ke dalam SPI kebersihan dan kesehatan, terdapat klinik kesehatan yang tersedia yang siap melakukan pertolongan pertama kepada penumpang yang membutuhkannya, adanya petugas kebersihan dan penyediaan tempat sampah, tetapi masih banyaknya penumpang yang membuang sampah sembarangan mengakibatkan keadaan stasiun yang terlihat kumuh dan kotor.

9. SPM fasilitas keselamatan dan kemananan dimasukkan ke dalam SPI keamanan, adanya petugas keamanan staisun yang selalu beroperasi untuk menjaga keamanan, pemberlakuan sistem boarding, pemasangan CCTV di tempat-tempat yang rawan, penyediaan alat pemadam kebakaran sederhana dan pemasangan alat alarm untuk pemberitahuan tanda bahaya.

10. SPM fasilitas penyandang cacat tidak diatur dalam SPI, fasilitas penyandnag cacat sudah disediakan di stasiun Lempuyangan seperti penyediaan peron yang diatur sedemikian rupa untuk mempermudah penyandang cacat seperti kemiringan ramp, dan penyediaan guiding block untuk mempermudah penyadang cacat.

11. SPI staf dan petugas yang tidak diatur dalam SPM, staf dan petugas di stasiun Lempuyangan terbagi menjadi 4 unit kerja yaitu Perjalanan Kereta Api dan Administrasi, Pelayanan Stasiun, Pelayanan Komersial Stasiun, dan Keamanan, Kesehatan, Kebersihan dan Ketertiban Stasiun, dimana masing-masing unit memiliki tugas dan fungsinya.

12. SPI pencahayaan yang tidak diatur dalam SPM, pengaturan pencahayaan di staisun Lempunyangan dimaksudkan untuk mempermudah akses penumpang dan kereta api yang beroperasi pada keadaan yang minim cahaya, sehingga pencahayaan diatur oleh petugas untuk memberikan kelancaran transportasi kereta api. 
Dalam penerapan SPM dan SPI di stasiun Lempuyangan Yogyakarta dipengaruhi oleh faktor-faktor. Faktor-faktor yang mempengaruhi implementasi kebijakan menurut Donald Van Meter dan Carl Van Horn sebagai berikut.

1. Ukuran-ukuran dan tujuan-tujuan yang jelas : dalam peraturan ini telah ditetapkan ukuran-ukuran SPM baik secara kualitas dan kuantitasnya yang harus disediakan disetiap stasiun dengan tujuan untuk memberikan pelayanan prima melalui penerapan SPM sebagai upaya untuk meningkatkan kualitas pelayanan publik dalam bidang transportasi kereta api.

2. Sumber-sumber kebijakan : terbagi menjadi sumber daya manusia, sumber daya finansial, dan sumber daya waktu yang dikelola oleh Kementerian Perhubungan dan PT KAI Persero.

3. Komunikasi antar organisasi dan kegiatan-kegiatan pelaksanaan : komunikasi antar aktor pelaksana yaitu Kementerian Perhubungan sebagai pembuat kebijakan, PT KAI Persero dan UPT stasiun sebagai pelaksana kebijakan, dan penumpang kereta api sebagai penerima kebijakan. Kegiatan pelaksanaan di staisun Lempuyangan yaitu SPI.

4. Karakteristik badan pelaksana : bersifat top down, segala peraturan ditetapkan oleh pusat yang harus diterapkan didaerah operasinya masing-masing dengan program pelaksanaan yang disesuaikan dengan karakteristik dan kondisi daerahnya masingmasing.

5. Kondisi ekonomi, sosial dan politik : Yogyakarta merupakan kota wisata dan kota pendidikan yang berbasis terhadap kebuadayaan tradisonal menyebabkan daya tarik kepada masyarakat untuk mengunjungi Yogyakarta, sehingga mempengaruhi pelayanan publik dalam bidnag transportasi di staisun Lempuyangan.

6. Kecenderungan pelaksana (implementors) : respon positif oleh Daerah Operasi VI Yogyakarta dan UPT staisun Lempuyangan dalam penerapan SPM dan SPI, sehingga stasiun Lempuyangan Yogyakarta mendapatkan juara ketiga dalam best stastion award 2013.

Dari faktor-faktor yang mempengaruhi implementasi kebijakan publik di atas, dapat diklasifikasikan ke dalam faktor pendukung yaitu komitmen SDM yang tinggi, dukungan pemerintah yang tinggi, keadaan sosial, ekonomi, dan politik Yogyakarta, dan jumlah penumpang yang banyak. Dan faktor penghambat yaitu keterbatasan luas tanag 
staisun Lempuyangan, kesadaran masyarakat yang masih rendah, pengadaan barang yang kurang maksimal, dan tidak adanya sanksi bagi yang melanggar peraturan.

\section{KESIMPULAN DAN SARAN}

\section{KESIMPULAN}

Berdasarkan hasil penelitian dapat disimpulkan bahwa: (1) peningkatan kualitas pelayanan publik melalui optimalisasi penerapan kebijakan transportasi di stasiun Lempuyangan Yogyakarta yaitu Peraturan Menteri Perhubungan Nomor 09 Tahun 2011 tentang Standar Pelayanan Minimum (SPM) untuk angkutan orang dengan kereta api sudah dilaksanakan secara optimal dengan membuat program pelaksanaan yaitu Service Performance Indicator (SPI) yang terdiri dari sebelas indikator yaitu (a) SPI Informasi, (b) SPI Kebersihan dan Kesehatan, (c) SPI Pelayanan Tiket, (d) SPI Keamanan, (e) SPI Staf dan Petugas, (f) SPI Ruang Tunggu, (g) SPI Fasilitas Umum, (h) SPI Peron, (i) SPI Parkir, (j) SPI Pencahayaan, dan (k) SPI Toilet, (2) penerapan SPM dan SPI secara optimal menjadikan stasiun Lempuyangan memperoleh juara ketiga dalam best station award 2013, (3) faktor-faktro yang mempengaruhi yaitu ukuran-ukuran dan tujuan-tujuan yang jelas, sumber-sumber kebijakan, komunikasi antar organisasi dan kegiatan-kegiatan pelaksanan, karakteristik (ciri-ciri atau sifat) badan pelaksana, kondisi ekonomi, sosial dan politik, dan kecenderungan pelaksana (implementors), selai itu faktor pendukunya yaitu komitmen SDM yang tinggi, dukungan pemerintah yang tinggi, keadaan sosial, ekonomi, dan politik Yogyakarta, dan banyaknya jumlah penumpang, dan faktor penghambatnya yaitu keterbatasan luas tanah, kesadaran masyarakat yang masih rendah, pengadaan barang yang kurang maksimal, dan tidak adanya sanksi bagi yang melanggar peraturan.

\section{SARAN}

Berdasarkan hasil penelitian terkait dengan peningkatan kualitas pelayanan publik melalui optimalisasi penerapan kebijakan transportasi di staisun Lempuyangan Yogyakarta, peneliti memberikan saran, sebagai berikut : a) peningkatan kemampuan dan keterampilan SDM di staisun Lempuyangan melalui training, workshop, Idan pelatihan, b)penggunaan lahan stasiun Lempuyangan secara maksimal, seperti pembangunan tempar parkir 2 lantai, c) penyediaan papan informasi digital yang mudah diakses oleh penumpang dan calon penumpang KA, d) pengadaan barang yang berorientasi dapat 
digunakan dalam jangka waktu yang lama, dan e) pemberlakuan sanksi yang tegas bagi yang melanggar peraturan yang ada.

\section{DAFTAR PUSTAKA}

Agus Dwiyanto. (2011). Mewujudkan Good Governace Melalui Pelayanan Publik. Yogyakarta : Gajah Mada University Press.

Budi Winarno. (2010). Kebijakan Publik : Teori, Proses, dan Studi Kasus. Yogyakarta : CAPS.

Departemen Perhubungan. 2005. Sistem Transportasi Nasional. Jakarta : -.

Miftahudin. (2009). Melihat Satsiun KA Lempuyangan yang Sudah Berbenah, (Online), (http://www.jogjainfo.net/2009/05/melihat-stasiun-ka-lempuyangan-yang.html pada tanggal 21 September 2013, Jam 03.00 WIB).

Peraturan Menteri Perhubungan Nomor 09 Tahun 2011 Tentang Standar Pelayanan Minimum Untuk Angkutan Orang Dengan Kereta Api.

PT KAI (Persero). 2013. Meningkatkan Kualitas Pelayanan Stasiun Melalui Best Station Award 2013, (Online), (http://www.keretaapi.co.id/?ndn8zph=Y29tX210aW5mb3JtYXNp\&_4zenp=ZGV0YWls\&_8ith=M $\underline{\text { TM3 }}$ pada tanggal 21 September 2013, Jam 02. 59 WIB).

Ratminto \& Atik S. Winarsih. (2010). Manajemen Pelayanan : Pengembangan Model Konseptual, Penerapan Ctizen's Charter dan Standar Pelayanan Minimum. Yogyakarta : Pustaka Pelajar.

Riant Nugroho. (2008). Kebijakan Publik (Analisis Kebijakan, Proses Kebijakan, Perumusan, Implementasi, Evaluasi, Revisi Risk Management Dalam Kebijakan Publik, Kebijakan Sebagai The Fifth Estate, Metode Penelitian Kebijakan). Jakarta : PT Elex Media Komputindo Kelompok Gramedia.

Sakti Adji Adisasmita. (2011). Jaringan Transportasi : Teori dan Analisis. Yogyakarta : Graha Ilmu.

Soemo Eko Saputro. (2007). Kebijakan Perkereta-apian, Ke Mana Hendak Bergulir?. Jakarta : Gibon Group.

Tukas Jonan. 2011. Ya, SPM Kereta Api Kok tanpa Sanksi, (Online), (http://ekbis.rmol.co/read/2011/02/27/19454/Ya,-SPM-Kereta-Api-Kok-TanpaSanksi...- pada tanggal 21 September 2013, Jam 02.50 WIB). 